\title{
BCR/PDGFRA Fusion Gene
}

National Cancer Institute

\section{Source}

National Cancer Institute. BCR/PDGFRA Fusion Gene. NCI Thesaurus. Code C99313.

A fusion gene that results from a chromosomal translocation $\mathrm{t}(4 ; 22)(\mathrm{q} 12 ; \mathrm{q} 11)$ which fuses either exon 7 or 12 of the BCR gene with exon 12 of the PDGFRA gene. This rearrangement is associated with CML-like myeloproliferative disease. 